\title{
Starch distribution in anthers, microspores and pollen grains in Aechmea recurvata (Klotzsch.) L.B.Sm., Dyckia racinae L.B.Sm. and Tillandsia aeranthos (Loisel.) L.B.Sm. (Bromeliaceae)
}

João Marcelo Santos de Oliveira ${ }^{1,2}$, Merielem Saldanha Martins ${ }^{3}$, Mariane Paludette Dorneles ${ }^{4}$ and Cesar Carvalho de Freitas ${ }^{3}$

Received: July 29, 2014. Accepted: September 15, 2014

\begin{abstract}
This paper presents a comparative description of the starch distribution in the anthers, microspores and pollen grains of Aechmea recurvata, Dyckia racinae and Tillandsia aeranthos. Flowers at different stages of development were processed according to plant microtechniques for observation by light microscope. Ten stages of embryological development were used as references for the comparative analysis of starch distribution and dynamics. The structural data showed a greater starch accumulation in the parietal layers and connective of $D$. racinae. It was observed that in the species studied, starch began to accumulate in microspore mother cell stage. The pollen grains in D. racinae and in T. aeranthos present two amylogenesis-amylolysis cycles, while A. recurvata presents only one. One amylogenesis-amylolysis cycle occurs in the parietal layers and/or connective tissue in all three species. The pollen grains in the three species are dispersed without starch and are characterized as the starchless type. Starch dynamics presents a close relation to the development of sporangia, microspores and pollen grains. It is believed that differences in the starch distribution and accumulation are related to the abiotic factors where the species are found.
\end{abstract}

Key words: carbohydrates, development, microgametogenesis, microsporogenesis, sporangium

\section{Introduction}

The effectiveness of the reproductive process in angiosperms depends on the viability of microspores, megaspores, pollen grains and embryo sac, where the dynamics and use of primary metabolites are essential in this process (Bhandari 1984; Delph et al. 1997; Shivanna 2003; Pacini et al. 2006; Konyar et al. 2013). The accumulation and mobilization of sugars, lipids and proteins are common during sporangia development and were demonstrated by microscopy, histochemistry, and biochemical, physiological and molecular assays (Pacini \& Viegi 1995; Oliver et al. 2005; Lora et al. 2012; Konyar et al. 2013). Regarding to the sugars, their importance was demonstrated for maturation of the epidermis, endothecium and tapetum (Clément \& Audran 1995; Clément et al. 1998; Castro \& Clément 2007). In this subject, was also demonstrated that the middle layers also act in the access of sugars to the loculus (Clément \& Audran 1995).

Besides to supply the metabolic demand, sugars will compose the fibrous thickenings of the endothecium, the primexine and intine, and in some cases, also the exine (Walter \& Doyle 1975; Horner \& Pearson 1978). When preparing for the developmental events of pollen grains, including the pollination period, sugars can be accumulated as starch, callose, pectins, insoluble polysaccharides, disaccharides or monosaccharides (Pacini 1996; Aouali et al. 2001; Clément \& Pacini 2001; Pacini et al. 2006). The starch acts on the metabolism or has a structural function (Pacini 1996). In metabolism, starch can be emphasized as an intermediate stage in the formation of oils in starchlesstype pollen grains (Miki-Hirosige \& Nakamura 1983; Baker \& Baker 1979). It may be possible for it to convert into sucrose for breathing and osmotic regulation (MikiHirosige \& Nakamura 1983), or as a source of energy for the germination and growth of the pollen tube (Clément et al. 1994; Franchi et al. 1996).

Biochemical analyses associated with histological identification show that starch is an important marker of stamen and pollen grain development. There is a close correlation between different stages of cell and tissue development in

\footnotetext{
${ }^{1}$ Professor Adjunto. Laboratório de Botânica Estrutural (LABOTE), Departamento de Biologia (CCNE). Universidade Federal de Santa Maria - UFSM. Avenida Roraima, nº 1000, Cidade Universitária. Departamento de Biologia, Prédio 16, sala 3253. Bairro Camobi. Santa Maria - RS. CEP $97105-900$.

${ }^{2}$ Autor para correspondência: linneau@yahoo.com.br

${ }^{3}$ Acadêmica(o) do curso de Ciências Biológicas, CCNE/UFSM. Bolsista REUNI.

${ }^{4}$ Mestre em Agrobiologia. Programa de Pós-Graduação em Agrobiologia, CCNE - UFSM.
} 
the anthers and mobilization of nutrients with the events of amylogenesis and amylolysis (Hess 1991; Noher de Halac et al. 1992; Pacini \& Viegi 1995; Clément et al. 1998; Konyar et al. 2013).

The accumulation of information on the dynamics of sugars and starch has consistently increased embryological knowledge, besides the traditional aspects of the differentiation of reproductive cells studied by means of sporogenesis and gametogenesis (Baker \& Baker 1979, 1983; Miki-Hirosige \& Nakamura 1983; Noher de Halac et al. 1992; Clément et al. 1994; Franchi et al. 1996). Thus, some patterns of sugars and starch dynamics are widely disseminated among the angiosperms. Others have a strong phylogenetic determination, as observed in some Asteraceae (Baker \& Baker 1983), and others are connected to the strategies to ensure pollen viability as a function of the environment, including biotic and abiotic aspects, such as the type of pollinator and the humidity (Baker \& Baker 1979, 1983; Lisci et al. 1994; Pacini 2000; Pacini et al. 2006).

According to Baker \& Baker (1979), two classes of pollen grains can be found among the angiosperms - one called the starchless type, i.e., with pollen grains containing little or no starch at the time of dispersion; the second called starchy, with pollen grains containing large amounts of starch at the time of dispersion. Often it is thought that the type of reserve is related to pollen viability and to the pollinating agent, and starchy pollen grains are less viable temporally than the starchless pollen grains, although there are exceptions due to pollen grain size (Baker \& Baker 1983).

Embryological studies associated with the recognition of metabolites, such as sugars or starch, as forms of reserve, generate important biological knowledge, in their structural, physiological, phylogenetic, ecological and evolutionary aspects. Although there are embryological results in Bromeliaceae, there is little information about the dynamics of metabolites or starch, during the staminal development or in mature pollen grains (Baker \& Baker 1979; Hess 1991;
Eva et al. 2006). However, so far, no studies dedicated to the comparative histological and histochemical analysis of different species have been conducted. Thus, considering the importance of starch as a way to accumulate carbohydrates, and its importance in differentiating anthers, pollen grains, and for the reproductive process in plants, it is intended: a) comparatively analyze the data obtained among the three species from different environments; and b) bring comprehension about starch distribution and its dynamics during different stages of anther and pollen development.

\section{Materials and methods}

Inflorescences with floral buds at different developmental stages of six specimens of Dyckia racinae L.B. Sm. (Fig. 1) were collected in the municipality of São Pedro do Sul, RS, Brasil (29 $\left.35^{\prime} 22,2^{\prime \prime} \mathrm{S} / 54^{\circ} 49^{\prime} 49,4^{\prime \prime} \mathrm{W}\right)$, eight specimens of Tillandsia aeranthos (Loisel.) L.B. Sm. (Fig. 2) in the municipality of São Sepé, RS (2954'47,9”'S/ 5341'07,2”W) and five specimens of Aechmea recurvata (Klotzsch.) L.B. Sm. (Fig. 3) in the municipality of Santa Maria, RS $\left(29^{\circ} 36^{\prime} 09,5^{\prime \prime} \mathrm{S} / 53^{\circ} 42^{\prime} 84,0^{\prime \prime} \mathrm{W}\right)$. Voucher specimens were deposited in the Herbarium of the Federal University of Santa Maria at Santa Maria, Rio Grande do Sul, Brazil (SMDB), under the accession numbers Dyckia racinae 13840, Tillandsia aeranthos 12950, and Aechmea recurvata 12949.

Aechmea recurvata (Klotzsch.) L.B. Sm. belongs to the subfamily Bromelioideae. Its individuals are small, epiphytes or rupicoles, rhizomatous, and they can be found exposed directly to the sun or in environments with diffuse light (Reitz 1983). For this study, epiphyte individuals of A. recurvata were collected, whose phorophytes were in a gallery forest. Tillandsia aeranthos (Loisel.) L.B. Sm. belongs to subfamily Tillandsioideae. It is also epiphytic and rhizomatous, found preferentially in an open environment or, more rarely, in an environment with diffuse light (Reitz 1983). For the present study, epiphytic individuals of T. aeranthos
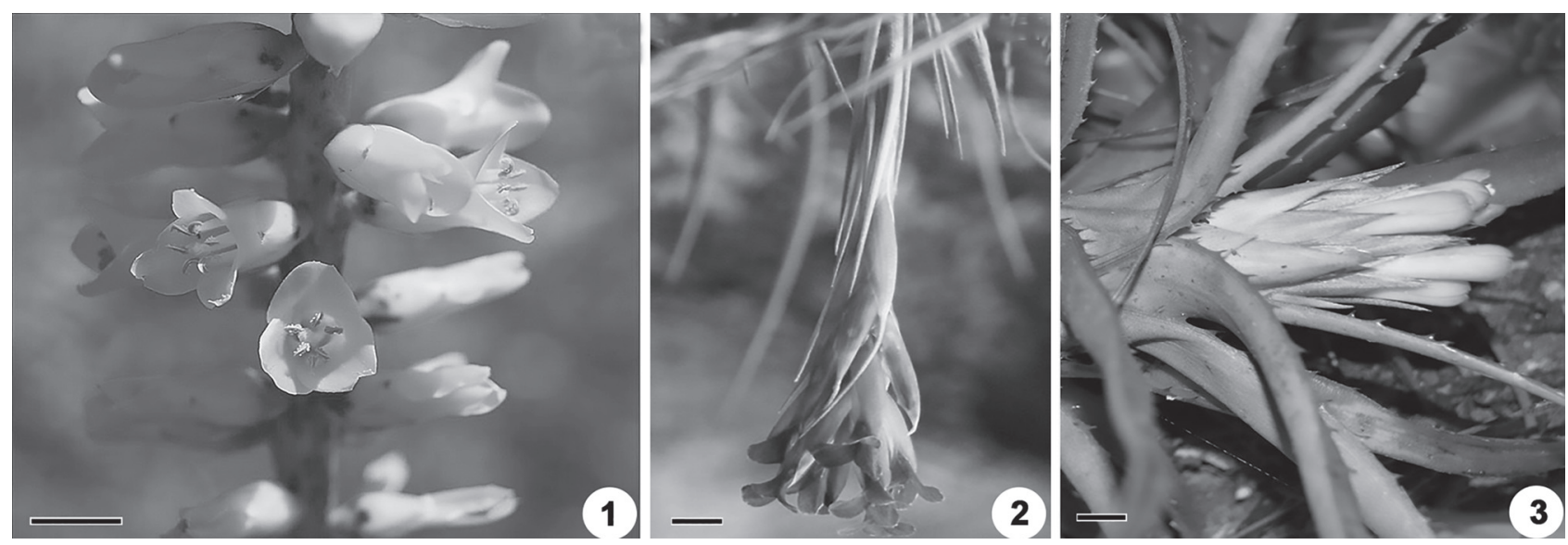

Figures 1-3. General aspect of species of Bromeliaceae during flowering. 1. Dyckia racinae L.B.Sm. (Pitcairnioideae); 2. Tillandsia aeranthos (Loisel.) L.B.Sm. (Tillandsioideae); 3. Aechmea recurvata (Klotzsch.) L.B.Sm. (Bromelioideae). Scale bars: $1=9 \mathrm{~mm} ; 2=5 \mathrm{~mm} ; 3=41 \mathrm{~mm}$. 
were collected, whose phorophytes were isolated in a field formation. Dyckia racinae L.B. Sm., belonging to subfamily Pitcairnioideae, is rhizomatous and terrestrial. It is found in a rocky environment and never in shade. The three species used in this study represent only three subfamilies that occur in Brazil. Moreover, the species are usually found in particular microenvironments, therefore, important to the proposed objectives in this study.

The floral samples were fixed in $1 \%$ glutaraldehyde and $4 \%$ formaldehyde (McDowell \& Trump 1976) in sodium phosphate buffer $0.1 \mathrm{M}, \mathrm{pH} 7.2$ (Gabriel 1982), dehydrated in an ethylic series. Embedding of flower samples was performed with 2-hydroxyethyl methacrylate (Gerrits \& Smid 1983). Sections with 2 to $5 \mu \mathrm{m}$ thick were made in a Leica RM2245 rotary microtome. Periodic Acid/ Schiff Reagent (PAS), combined with Toluidine Blue O, in a sodium benzoate buffer, pH 4.4 (Feder \& O’Brien 1968; O’Brien \& McCully 1981), were used to stain tissue and to simultaneously identify starch. PAS was used to identify starch in mature pollen grains (O’Brien \& McCully 1981). The analysis and photomicrographs were performed using a Leica DM2000 microscope.

In the present study, ten stages of embryological development were used as references for analysis and comparison, of the three species, namely: microspore mother cell, dyad of microspores, tetrad of microspores, callose dissolution, free microspores, vacuolation, $1^{\text {st }}$ haploid mitosis, initial gametogenesis (generative cell - lens shape whit parietal position), middle gametogenesis (generative cell moved from its parietal position), final gametogenesis (male germ unit formed). Such stages are traditionally used as morphological and developmental markers to the embryological study in angiosperms (Bhandari 1984; Knox 1984; Johri et al. 1992; Batygina 2002; Lersten 2004).

\section{Results and discussion}

In the three species studied, ten distinct stages of development during sporogenesis and gametogenesis were defined (Tab. 1). The comparative observation and analysis of the presence of starch occurred in anthers, microspores and pollen grains, and the microspore mother cell was the initial stage of the studies (Figs. 4-9). In A. recurvata, $D$. racinae and T. aeranthos, they have four sporangia with five to six layers each, namely: epidermis, endothecium, two to three middle layers and tapetum (Figs. 4-12). The tapetum surrounds completely the meiocytes. The connec-

Table 1. 1. Microspore mother cell; 2. Dyad of microspores; 3 . Tetrad of microspores; 4. Callose dissolution; 5 . Free microspores; 6 . Vacuolation; 7. $1^{\text {st }}$ haploid mitosis; 8. Initial gametogenesis (generative cell - lens shape and parietal position); 9. Middle gametogenesis (generative cell moved from its parietal position); 10. Final gametogenesis (male germ unit formed). Hollow inverted triangle indicates the beginning of epidermal cell and endothecium growth. Full triangle indicates formation of endothecium thickening. Hollow triangle indicates amylogenesis peak in the pollen grain. Continuous line indicates amylogenesis. Dotted line indicates amylolysis.

\begin{tabular}{|c|c|c|c|c|c|c|c|c|c|c|c|}
\hline & & \multicolumn{10}{|c|}{ Developmental stages } \\
\hline Species & Anther & 1 & 2 & 3 & 4 & 5 & 6 & 7 & 8 & 9 & 10 \\
\hline Dyckia racinae & & & & & . & $\nabla$ & & 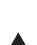 & & & \\
\hline Tillandsia aeranthos & Sporangium & & & & - - & & & & & & \\
\hline Aechmea recurvata & & & & & & 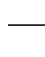 & & & & & \\
\hline Dyckia racinae & & & & & & & & & & & \\
\hline Tillandsia aeranthos & Connective & & & & 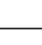 & - & & & & & \\
\hline Aechmea recurvata & & & & & - & & & & & & \\
\hline Dyckia racinae & & - & & & & & & & & & \\
\hline Tillandsia aeranthos & Meiocytes & 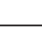 & & & & & & & & & \\
\hline Aechmea recurvata & & - - & & & & & & & & & \\
\hline Dyckia racinae & & & & & & $-\ldots$ & & & & & \\
\hline Tillandsia aeranthos & Microspores & & & & -. & & $-\ldots$ & & & & \\
\hline Aechmea recurvata & & & & & & & & - & & & \\
\hline Dyckia racinae & & & & & & & & & $\underline{\Delta}$ & & \\
\hline Tillandsia aeranthos & Pollen grains & & & & & & & & $\underline{\Delta}$ & _ & \\
\hline Aechmea recurvata & & & & & & & & & $\Delta$ & & \\
\hline
\end{tabular}



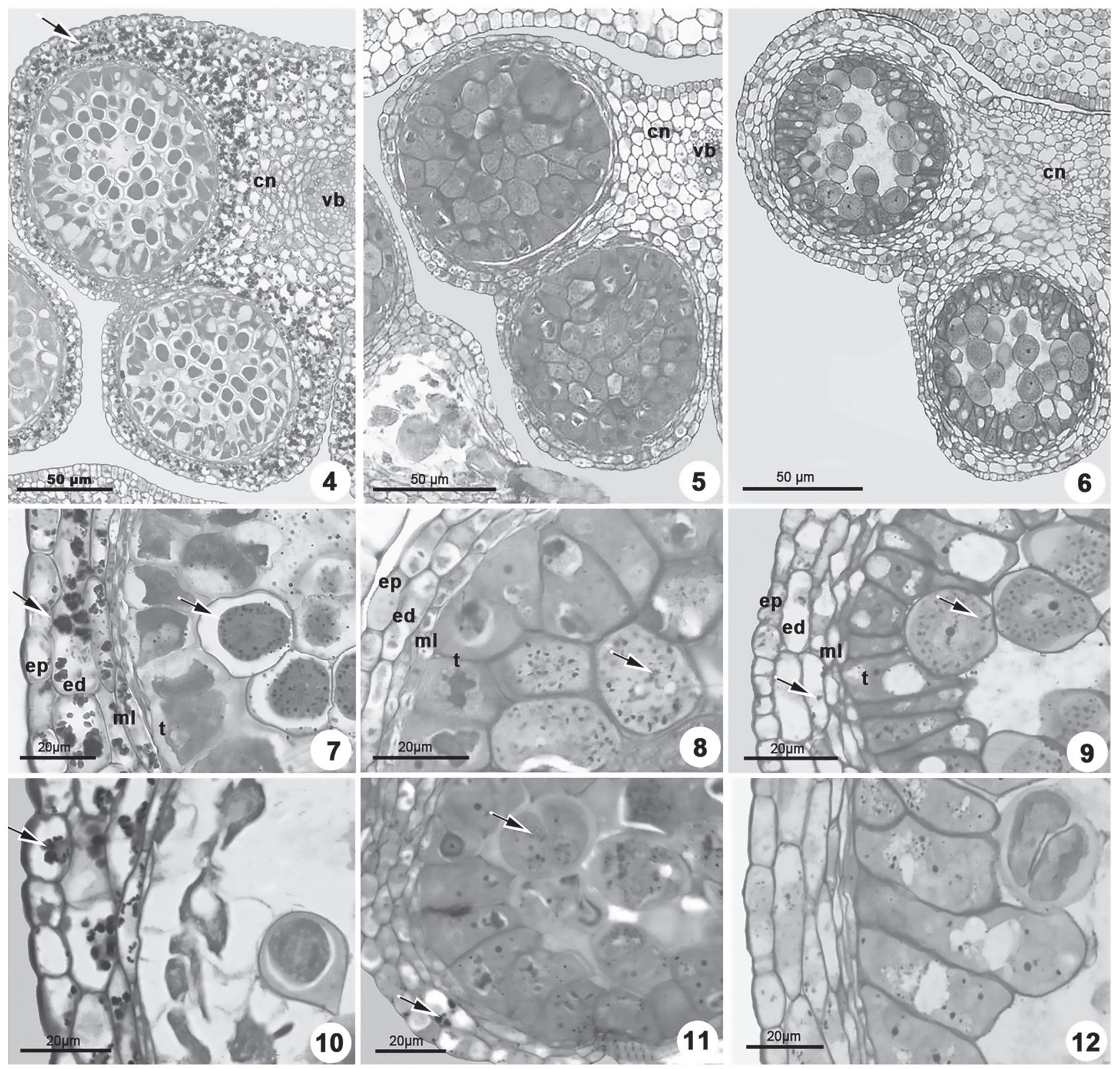

Figures 4-12. Cross sections of anther of the Bromeliaceae species. 4, 7, 10 - Dyckia racinae L.B.Sm.; 5, 8, 11 - Tillandsia aeranthos (Loisel.) L.B.Sm.; 6, 9, 12 - Aechmea recurvata (Klotzsch.) L.B.Sm.; 4, 5, 6 - General view of the sporangia during microspore mother cell stage; 7, 8, 9 - Detail of parietal layers during microspore mother cell stage; 10,11, 12 - Detail of the parietal layers and microspore dyads. Starch indicated by the arrows.

$\mathbf{e p}=$ epidermis, $\mathbf{e d}=$ endothecium, $\mathbf{m l}=$ middle layer $(\mathrm{s}), \mathbf{t}=$ tapetum, $\mathbf{c n}=$ conective, $\mathbf{v b}=$ vascular bundle .

tive is composed of parenchymatic tissue, with a collateral vascular bundle in the center (Figs. 4-6, 13-15).

General observation showed differences among the three species regarding the intensity of amylogenesis, stages to begin amylogenesis or amylolysis, or time period in which the starch remained accumulated (Tab. 1). It was also observed that all tissues or reproductive cells in the anthers presented at least one event of amylogenesis and amylolysis (Tab. 1).

In stage 1 (Tab. 1), in D. racinae, starch grains were observed in the connective, parietal layers (Figs. 4-7). In T. aeranthos, starch grains were observed only in the microspore mother cells (Figs. 5, 8). In A. recurvata, few starch grains were observed in the parietal layers (Figs. 6, 9). In the microspore mother cell, starch grains are similar in size and number to the other two species (Fig. 9). At this stage of development, only in D. racinae occurs starch accumulation in the connective.

According to Pacini (1996), the accumulation of starch indicates a greater availability of carbohydrates from the sporophyte because of a lower consumption by the gametophyte. It is important to consider that the greater expo- 
sure of $D$. racinae individuals to sunlight may be helping to provide more sugars, as demonstrated by the presence of starch grains. In the angiosperms, in general, meiosis and tetrad formation require an accumulation of sugars demonstrated by the callose wall deposition. Thus, there is a demand for sugars before gametogenesis. The callose wall was observed in this study, and its thickness in the analyzed species was similar (Figs. 10-12). In Triticum aestivum, it was demonstrated that the great accumulation of starch in the connective was associated with hydric stress because of the inhibition of the use of sucrose in the anther (Lalonde et al. 1997). In D. racinae, unlike the two other species, individuals whose flowers were collected, besides being exposed to constant luminosity, were found in shallow, rocky soil - a condition that shows there is less water available. The environmental characteristics described above are typical of those related to the vegetative structure of Dyckia and sites where their species occur (Benzing 2000). Thus, although the environmental conditions are well supported by the vegetative organs, it is not yet possible to determine whether the amount of starch in the connective reveals a favorable aspect of luminosity or an unfavorable one of hydric stress.

The beginning of starch accumulation in the reproductive tissue in anthers is generally recorded during the vacuolation stage of the microspores or during the bicellular pollen grain stage (Pacini 1996). In this way, the results of the present study demonstrated that the accumulation of starch in reproductive tissue may occur earlier in the development, i.e., during meiosis (Figs. 10, 11, 12, Tab.1). It was described that in Tillandsia pallidoflavens (Hess 1991) and in Lilium henryi (Dickinson 1981), the plastids in the archesporial cells accumulate polysaccharides. In Smilax aspera (Pacini \& Franchi 1983), in Lilium longiflorum (Miki-Hirosige \& Nakamura 1983) and in Oenothera hookeri (Noher de Halac et al. 1992), the occurrence of starch grains in the microspore mother cells was described. An analysis of the literature showed that there is variability in this aspect, including species of a same genus as in Lilium (Dickinson 1981; Clément et al. 1994).

During stage 2 (Tab. 1), a reduction in the amount and size of starch grains in the sporangia and connective tissues is observed, besides the disappearance of the grains in the meiocytes in D. racinae (Fig. 10). In T. aeranthos, the starch grains diminish in number and size in the microspore dyads (Fig. 11), although, sometimes, they have been found in the sporangia. In this species, sugars PAS-positive in the tapetal vacuoles are maintained, although their quantity is relatively diminished (Fig. 11). In A. recurvata, no changes are observed in the starch grains or parietal layers. Only amylolysis occurs in the microspore dyads (Fig. 12).

In stage 3 (Tab. 1), in D. racinae, amylolysis was observed in the connective (Figs. 13, 16). In T. aeranthos, there was a small accumulation of starch grains in the epidermis, endothecium, tapetum (Fig. 17), and in the connective cells close to the internal tapetum (Fig. 14). In T. aeranthos, it was common to find the accumulation of PAS-positive sugars in the vacuoles in the cells of the connective and of the parietal layers. In A. recurvata, was observed a discrete increase in starch grains number in the parietal layers except in the tapetum (Fig. 18). In the three species of the present study, no starch grains were observed in the microspores in the tetrad (Figs. 16-18).

In $D$. racinae, the tapetal tissue collapses earlier compared with T. aeranthos and A. recurvata, presenting signs of collapse in the dyad stage (Figs. 10,13, 16, 19), when callose dissolution is observed (Fig. 10) (Tab. 1). T. aeranthos does not show signs of tapetal cell collapse and does not present callose dissolution in the dyad stage of the microspores (Fig. 11). In A. recurvata, the beginning of callose dissolution during the dyad stage is observed, although the tapetum does not show signs of collapse (Figs. 9 and 12). In D. racinae and in T. aeranthos, at the end of the callose dissolution (stage 4), total amylolysis occurs in the sporangia. The growth of epidermal cells in both species occurs during the same stage (Figs. 4-6, 7-12, Tab. 1), followed by thickening of the endothecium in D. racinae and in two later stages in T. aeranthos.

In stage 5 (Tab. 1), starch grains are observed in the epidermis and in the endothecium in D. racinae and in $T$. aeranthos (Figs. 19, 20). However, in D. racinae (Fig. 19), the starch appears as the remnant of an amylolysis process, contrary to what was observed in T. aeranthos, where the amount and size of the grains are greater than in the previous stage (Fig. 20, Tab. 1). In the free microspores, when the exine is beginning to form, starch grains are observed in D. racinae and in A. recurvata and at the beginning of accumulation in T. aeranthos (Figs. 19-21). At this stage, it was observed that the cells of the middle layers, mainly the inner middle layer, are compressed in the three species studied (Figs. 19, 21). Additionally, even in the regions where the outer middle layer is not compressed, no starch grains were observed (Figs. 19-21). At the end of stage 5, total amylolysis occurs in the sporangium in A. recurvata, being observed in stages 6 and 7 epidermal cells growth and endothecium thickening.

In stage 6 (Tab. 1) in D. racinae, the starch in the microspores is almost totally consumed, compared to the other stages and species (Figs. 22-29). During this stage, when compared to the previous stage, greater thickening of the intine can be observed in the aperture region (Fig. 23). The intine in T. aeranthos (Figs. 24, 28) and in A. recurvata (Figs. $26,29)$ increases its thickening during the first mitosis in the pollen grains. In Anacardium occidentale, amylolysis and differentiation of the intine in the pollen apertures were also observed in the vacuolation phase (Oliveira \& Mariath 2001; Oliveira et al. 2001). Santos \& Mariath (1999) described very similar aspects in Ilex paraguariensis, and the authors suggested the connection between amylolysis and the increased thickening of the intine.

In $D$. racinae, at the end of the microspore vacuolation (Tab. 1), the starch grains disappear in the parietal layers, 


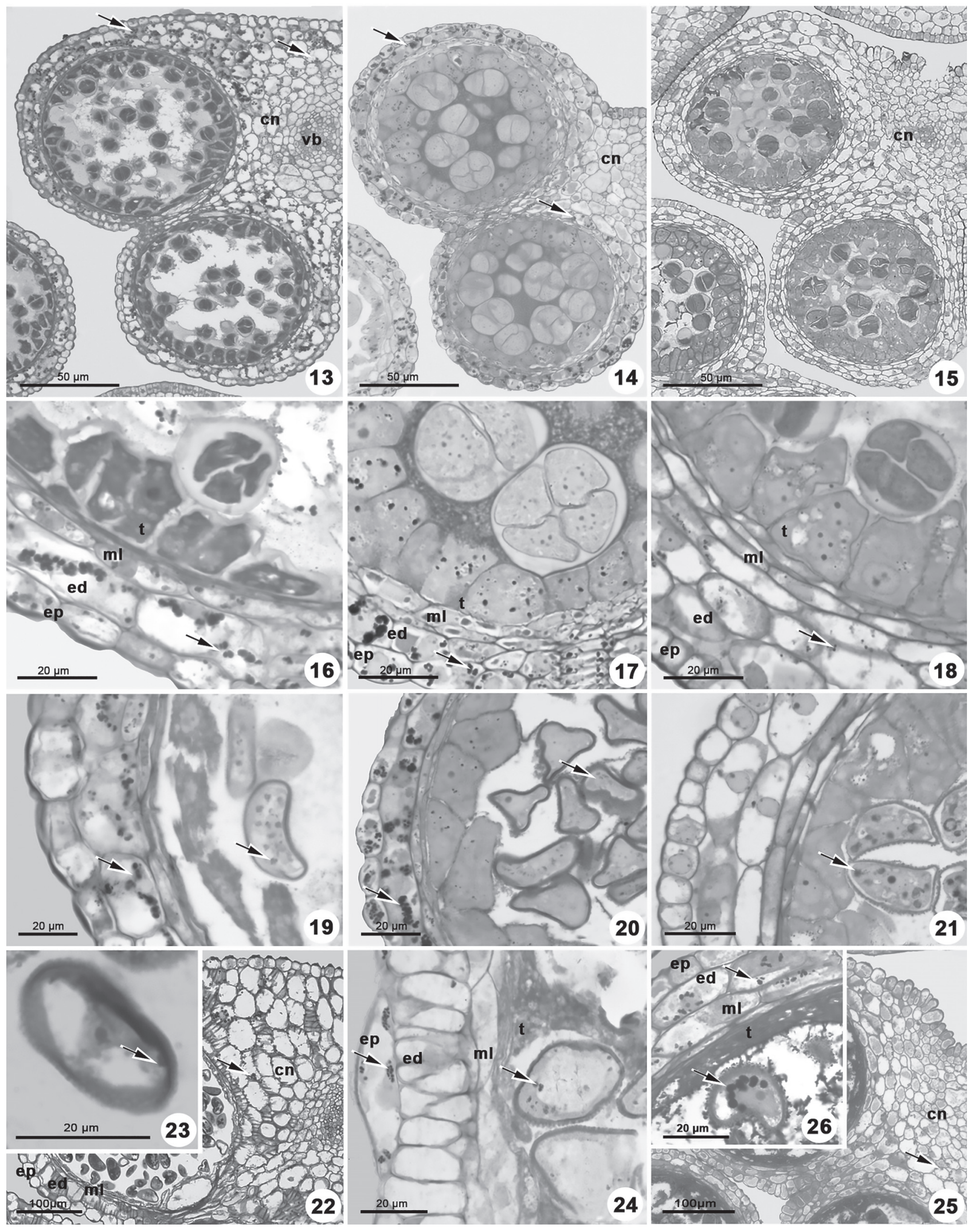

Figures 13-26. Cross sections of anther of the Bromeliaceae species. 13, 16, 19 - Dyckia racinae L.B.Sm.; 14, 17, 20 - Tillandsia aeranthos (Loisel.) L.B.Sm.; 15, 18, 21 - Aechmea recurvata (Klotzsch.) L.B.Sm.; 13, 14, 15 - General view of the sporangia in the microspore tetrad stage; 16, 17,18 - Detail of parietal layers and tetrad of microspores; 19, 20, 21 - Detail of parietal layers and free microspores in the loculus; 22, 24,25 - Detail of the connective and parietal layers. 22 - Note connective cells with U-shaped thickening; 23, 24, 26 - Vacuolated microspores. Starch indicated by the arrows.

ep $=$ epidermis, $\mathbf{e d}=$ endothecium, $\mathbf{m l}=$ middle layer $(\mathrm{s}), \mathbf{t}=$ tapetum, $\mathbf{c n}=$ conective, $\mathbf{v b}=$ vascular bundle. 
which were possibly used for cell lengthening or for construction of the U-shaped thickening typical to the endothecium - aspects of cell differentiation that can be observed when comparing the development stages (Figs. 19, 22).

In $T$. aeranthos there is marked cell growth in the epidermis and endothecium during vacuolation (Figs. 20,24), although the beginning of the differentiation of endothecium thickenings occurs in the later phase (Fig. 28).

In A. recurvata, in stage 6 (Tab. 1), the size of the starch grains increased compared to the previous stages (Figs. 25, 26). In the parietal layers of this species, amylogenesis occurred in the endothecium and in the outer middle layer (Fig. 26). As for the other two species, there was no differentiation in the epidermis or endothecium cells (Fig. 26). According to Clément \& Pacini (2001), the first cycle of starch degradation may be related to anther growth or to the formation of endothecium thickenings. When the results of the present study are analyzed, there is variability between species to begin endothecium differentiation and also for the starch dynamics in the sporangia. Because of the differentiation of the epidermis and endothecium, including the formation of their thickening, it is believed that these persistent layers of the sporangia are also important sinks for sugars from amylolysis. In the three species analyzed, the differentiation of the epidermis occurs during or after amylolysis, while the growth and formation of endothecium thickening occurs later, although these events occur at different stages (Tab. 1).

The structural changes observed in the sporangia, mainly growth of the endothecium and epidermis cells, formation of endothecium thickenings and loss of starch grains, according to Keijzer (1987), form the first set of changes related to the anthers dehiscence. In different species (Keijzer 1987; Noher de Halac et al. 1992) the processes were similar to those described here for D. racinae, T. aeranthos and $A$. recurvata, although the time at which they occur is similar only for the first two species. In A. recurvata the same processes occurs relatively late.

After the first pollen mitosis starch grains were observed in the pollen grains in D. racinae and in T. aeranthos (Figs. $27,28)$, during the same stage, there is an increase in the number of starch grains in A. recurvata (Fig. 29). No starch grains were observed in the sporangium and in the connective (Figs. 30-32). In the three studied species of Bromeliaceae, starch was observed only in the vegetative cell, and this is a common characteristic of the angiosperms (Knox 1984; Johri et al. 1992). In this study, the starch grains found in the vegetative cell are relatively larger than those observed in the different anther tissues, meiocytes or microspores (Figs. 22-24).

Pacini \& Viegi (1995) and Pacini (1996) described development and amylogenesis stages for meiocytes, microspores and pollen grains, similar to those described in the present work, especially in relation to $D$. racinae. For the angiosperms, Pacini \& Franchi (1988) considered that the last amylogenesis cycle would usually be more intense, as observed in this study. Beginning with the maximum amylogenesis observed, the later stages were marked by a progressive assimilation of these reserves, culminating in starchless pollen grains during the dispersion phase (Figs. 31-36, Tab. 1). The results of this study support the data presented by Baker \& Baker (1979), who considered the occurrence of pollen grains without starch for the Bromeliaceae, i.e., of the starchless type. However, all the species analyzed presented a positive PAS cytoplasm (Figs. 36-38). PAS-positive polysaccharides were found in the mature pollen grains cytoplasm in Mercurialis annua and Ricinus communis (Franchi et al. 1996), and in Trachycarpus fortunei (Guarnieri et al. 2006). Soluble polysaccharides are also found in mature starchless pollen grains, but they are only detected using other methodologies, especially biochemical analyses (O’Brien \& McCully 1981; Pacini 1996; Castro \& Clément 2007; Speranza et al. 1997; Jain et al. 2007).

Speranza et al. (1997) and Clément \& Pacini (2001) demonstrated that, for different species, the PAS-positive cytoplasm of the vegetative cells is closely related to pollen grains dehydration at the time of their release, which presents a great viability after they are released, and are always associated with a dry environment. This longevity is related to the presence of sugars from amylolysis, which is associated with stabilization of membranes, water retention or absorption, especially during dehydration and transport of pollen grains (Lisci et al. 1994; Pacini 1996). Among the activities inherent to the vegetative cell that involve using sugars, are the construction of the intine, participation in the formation of the male germ unit, and formation of the pollen tube, besides the energy demand of the cell itself (Pacini et al. 2006; Pacini \& Franchi 1983). Miki-Hirosige \& Nakamura (1983), analyzing Lilium longiflorum, and Eva et al. (2006) analyzing Tillandsia seleriana, showed that the vegetative cell was responsible for supplying the reserves used during the development of the generative cell and for the emission of the pollen tube.

At the beginning of the bicellular pollen grain stage, starch is no longer observed in the parietal layers or in the connective in the species analyzed in the present study (Tab. 1). In the mature or dehiscent anther, no starch grains are found in pollen grains, and few starch grains are observed in the connective or parietal layers (Figs. 30-38).

Amylogenesis and amylolysis occur in the anther wall and throughout its development, in the microspores mother cells, microspores and pollen grains in this study. One amylogenesis-amylolysis cycle occurs in the parietal layers and/ or connective tissue in all three species. In Dyckia racinae and Tillandsia aeranthos was observed in the microspores one cycle of amylogenesis-amylolysis and one cycle in the pollen grains. In Aechmea recurvata only one cycle occurs, beginning during microsporogenesis and ending during the microgametogenesis. 

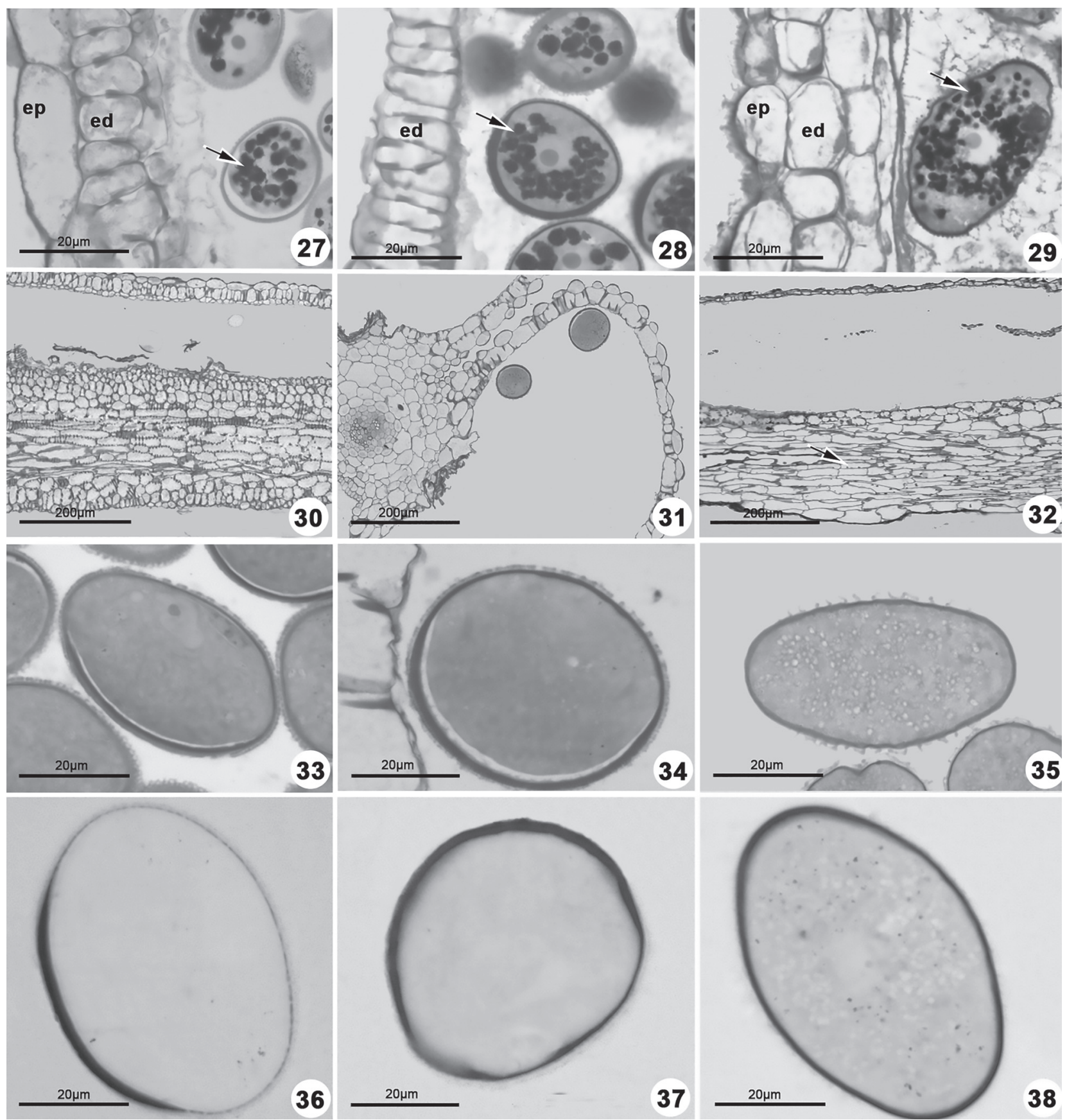

38

Figures 27-38. Pollen grains at different stages of development. 27, 30, 33, 36 - Dyckia racinae L.B.Sm.; 28, 31, 34,37 - Tillandsia aeranthos (Loisel.) L.B.Sm.; 29, 32, 35, 38 - Aechmea recurvata (Klotzsch.) L.B.Sm.; 27, 28, 29 - Detail of parietal layers and pollen grains in the initial gametogenesis. Anthers in longitudinal section; 30, 31, 32 - General view of connective and parietal layers of the anthers at anthesis. Anthers in longitudinal section in Figures 30 and 32 . Anther in cross section in Figure 31; 33, 34, 35 - Mature pollen grains in anthers in pre-anthesis; 36, 37, 38 - Mature pollen grains after PAS reaction. Anthers at anthesis. Starch indicated by the arrows.

ep $=$ epidermis, $\mathbf{e d}=$ endothecium .

The pollen grains in Dyckia racinae, Tillandsia aeranthos and Aechmea recurvata are not dispersed with starch, which characterizes the species as starchless type. In various species, the sugars in the cytoplasm are associated with the quiescence of the pollen grains, maintaining their viability and also associated with dry environments or entomophily (Baker \& Baker 1979; Lisci et al. 1994; Pacini 2000; Pacini et al. 2006).
The greater amount of starch observed in the connective tissue in $D$. racinae indicates a great availability of carbohydrates from the sporophyte that shows itself as a probable result of the greater exposure to sunlight radiation typical of the place where it occurs. The analysis of development showed that the connective is a buffer for the sugar surplus in the anther (Clément \& Pacini 2001). 
Considering the sporangial structure of the three species, all of them have a structure similar to each other and to the other angiosperms, where the spore and gametophyte formation process requires the mobilization of sugars, as well as the structure for anther dehiscence. Thus, from the connective, regardless of whether there was an availability of surplus sugars by the sporophyte, the amylogenesis products have the sporangium and pollen grains as sinks.

\section{Acknowledgments}

The authors thank Dr. Thaís Scott of Canto-Dorow, at the Federal University of Santa Maria, for the taxonomic determination of Dyckia racinae; the financial support via Official Announcement PRONEX (FAPERGS-CNPq ${ }^{\circ}$ 008/2009); CAPES, for master's scholarships for Mariane Paludette Dorneles and Cristiele Spat; financial support, through REUNI Scientific Initiation Scholarships granted by the Federal University of Santa Maria for graduate students Meriélem Saldanha Martins and César Carvalho de Freitas. The authors also thank Dr. Jaqueline Sarzi Sartori and M.Sc. Cristiele Spat for technical support.

\section{References}

Aouali N, Laporte P, Clément C. 2001. Pectin secretion and distribution in the anther durin pollen development in Lilium. Planta 213: 71-79.

Baker HG, Baker I. 1979. Starch in Angiosperm pollen grains and its evolutionary significance. American Journal of Botany 66: 591-600.

Baker HG, Baker I. 1983. Some evolutionary and taxonomic implications of variation in the chemical reserves of pollen. In: Mulcahy DL, Ottaviano E. (eds.) Pollen: Biology and Implications for Plant Breeding. New York, Elsevier. p. 43-52.

Batygina TB. 2002. Embryology of Flowering Plants. Terminology and Concepts. Vol. I. Enfield, Science Publishers Inc.

Benzing DH. 2000. Bromeliaceae: profile of an adaptive radiation. Cambridge, Cambridge University Press.

Bhandari NN. 1984. The Microsporangium. In: Johri BM. (ed.) Embryology of Angiosperms. Berlin Springer-Verlag. p. 53-121.

Castro AJ, Clément C. 2007. Sucrose and starch catabolism in the anther of Lilium during its development: a comparative study among the anther wall, locular fluid and microspore/pollen fractions. Planta 225: 1573-1582.

Clément C, Audran JC. 1995. Anther wall layers control pollen sugar nutrition in Lilium. Protoplasma 187: 172-181.

Clément C, Chavant L, Burrus M, Audran JC. 1994. Anther starch variations in Lilium during pollen development. Sexual Plant Reproduction 7: $347-356$

Clément C, Laporte P, Audran JC. 1998. The loculus content and tapetum during pollen development in Lilium. Sexual Plant Reproduction 11: 94-106.

Clément C, Pacini E. 2001. Anther plastid in Angiosperm. The Botanical Review 67: 55-73.

Delph LF, Johannsson MH, Stephenson AG. 1997. How environmental factors affect pollen performance: ecological and evolutionary perspectives. Ecology 78: 1632-1639.

Dickinson HG. 1981. The structure and chemistry of plastid differentiation during male meiosis in Lilium henryi. Journal of Cell Science 52: 233-241.

Eva M, Papini A, Brighigna L. 2006. Ultrastructural studies on bicellular pollen grains of Tillandsia seleriana Mez (Bromeliaceae), a neotropical epiphyte. Caryologia 59: 88-97.
Feder N, O’Brien TP. 1968. Plant microtechnique. Some principles and new methods. American Journal of Botany 55: 123-142.

Franchi GG, Bellani L, Nepi M, Pacini E. 1996. Types of carbohydrate reserves in pollen: localization, systematic distribution and ecophysiological significance. Flora 191: 1-17.

Gabriel BL. 1982. Biological Electron Microscopy. New York, Van Nostrand Reinhold Company.

Gerrits PO, Smid L. 1983. A new less toxic polymerization system for the embedding of soft tissue in glycol methacrylate and subsequent preparing of serial sections. Journal of Microscopy 132: 81-85.

Guarnieri M, Speranza A, Nepi M, Pacini E. 2006. Ripe pollen carbohydrate changes in Trachycarpus fortunei: the effect of relative humidity. Sexual Plant Reproduction 19: 117-124.

Hess MW. 1991. Ultrastructure of organelles during microsporogenesis in Tillandsia pallidoflavens (Bromeliaceae). Plant Systematics and Evolution 176: 63-74.

Horner HT, Pearson CB. 1978. Pollen wall aperture development in Helianthus annuus (Compositae: Heliantheae). American Journal of Botany 65: 293-309.

Jain M, Prasad PVV, Boote KJ, Hartwell Jr. AL, Chourey PS. 2007. Effects of season-long high temperature growth conditions on sugar-to-starch metabolism in developing microspores of grain sorghum (Sorghum bicolor L. Moench). Planta 227: 67-79.

Johri BM, Ambegaokar KB, Srivastava PS. 1992. Comparative Embryology of Angiosperms. Berlin, Springer-Verlag.

Keijzer CJ. 1987. The processes of anther dehiscence and pollen dispersal. 1. The opening mechanism of longitudinally dehiscing anthers. New Phytologist 105: 487-498.

Knox RB. 1984. The pollen grain. In: Johri BM. (ed.) Embryology of Angiosperms. Heidelberg, Springer-Verlag. p. 197-271.

Konyar ST, Dane F, Tütüncü S. 2013. Distribution of insoluble polysaccharides, neutral lipids, and proteins in the developing anthers of Campsis radicans (L.) Seem. (Bignoniaceae). Plant Systematics and Evolution 299: 743-760.

Lalonde S, Beebe DU, Saini HS. 1997. Early signs of disruption of wheat anther development associated with the induction of male sterility by meiotic-stage water deficit. Sexual Plant Reproduction 10: 40-48.

Lersten NR. 2004. Flowering Plant Embryology with Emphasis on Economic Species. Iowa, Blackwell Publishing.

Lisci M, Tanda C, Pacini E. 1994. Pollination ecophysiology of Mercurialis annua L. (Euphorbiaceae), an anemophilous species flowering all year round. Annals of Botany 74: 125-135.

Lora J, Herrero M, Hormaza JI. 2012. Pollen performance, cell number, and physiological state in the early-divergent angiosperm Annona cherimola Mill. (Annonaceae) are related to environmental conditions during the final stages of pollen development. Sexual Plant Reproduction 25: 157-167.

McDowell EM, Trump BR. 1976. Histological fixatives for diagnostic light and electron microscopy. Archives of Pathology \& Laboratory Medicine 100: 405-414.

Miki-Hirosige H, Nakamura S. 1983. Growth and differentiation of amyloplasts during male gamete development in Lilium longiflorum. In: Mulcahy DL, Ottaviano E. (eds.) Pollen: Biology and Implications for Plant Breeding. Amsterdam, Elsevier Biomedical. p. 141-147.

Noher de Halac I, Fama G, Cismondi IA. 1992. Changes in lipids and polysaccharides during pollen ontogeny in Oenothera anthers. Sexual Plant Reproduction 5: 110-116.

O'Brien TP, McCully ME. 1981. The study of plant structure principles and selected methods. Melbourne, Termarcarphi Pty Ltd.

Oliveira JMS, Mariath JEA. 2001. Anther and pollen development in Anacardium occidentale (Anacardiaceae) clone CP76. Phytomorphology 51: 91-100.

Oliveira JMS, Mariath JEA, Bueno DM. 2001. Desenvolvimento floral e estaminal no clone CP76 de Anacardium occidentale L. cajueiro-anãoprecoce (Anacardiaceae). Revista Brasileira de Botânica 24: 377-388. 
Oliver SN, Van Dongen JT, Alfred SC, et al. 2005. Cold-induced repression of the rice anther-specific cell wall invertase gene OSINV4 is correlated with sucrose accumulation and pollen sterility. Plant, Cell and Environment 28: 1534-1551.

Pacini E. 1996. Types and meaning of pollen carbohydrate reserves. Sexual Plant Reproduction 9: 362-366.

Pacini E. 2000. From anther and pollen ripening to pollen presentation. Plant Systematics and Evolution 222: 19-43.

Pacini E, Franchi GG. 1983. Pollen grain development in Smilax aspera L. and possible function of the loculus. In: Mulcahy DL, Ottaviano E. (eds.) Pollen: Biology and Implications for Plant Breeding. Amsterdam, Elsevier Biomedical. p. 183-190.

Pacini E, Franchi GG. 1988. Amylogenesis and amylolysis during pollen grain development. In: Cresti M, Gori P, Pacini E. (eds.). Sexual Reproduction in Higher Plants. Heidelberg, Springer-Verlag. p. 181-186.

Pacini E, Viegi L. 1995. Total polysaccharide content of developing pollen in two angiosperm species. Grana 39: 237-241.
Pacini E, Guarnieri M, Nepi M. 2006. Pollen carbohydrates and water content during development, presentation, and dispersal: a short review. Protoplasma 228: 73-77.

Reitz R. 1983. Bromeliáceas e a malária-bromélia endêmica. Flora Ilustrada Catarinense (Bromeliáceas).

Santos RP, Mariath JEA. 1999. Storage substances in the androgametogenesis and mature pollen grain of Ilex paraguariensis St. Hil. (Aquifoliaceae). Revista Brasileira de Botânica 22: 125-131.

Shivanna KR. 2003. Pollen Biology and Biotechnology. Enfield, Science Publishers, Inc.

Speranza A, Calzoni GL, Pacini E. 1997. Occurrence of mono or disaccharides and polysaccharides reserves in mature pollen grain. Sexual Plant Reproduction 10: 110-115.

Walter JW, Doyle JA. 1975. The bases of the Angiosperm phylogeny: palynology. Annals of the Missouri Botanical Garden 62: 664-723. 